\begin{tabular}{ll|l} 
Case Reports in & \multicolumn{2}{c}{ Case Rep Gastroenterol 2014;8:199-205 } \\
\cline { 2 - 3 } Gastroenterology & $\begin{array}{l}\text { DOI: 10.1159/000363566 } 2014 \text { S. Karger AG, Basel } \\
\text { Publisned online: June 4, 2014 }\end{array}$ & $\begin{array}{l}\text { 1662-0631/14/0082-0199\$39.50/0 } \\
\text { www.karger.com/crg }\end{array}$ \\
\cline { 2 - 3 } & $\begin{array}{l}\text { This is an Open Access article licensed under the terms of the Creative Commons } \\
\text { Attribution-NonCommercial 3.0 Unported license (CC BY-NC) (www.karger.com/OA- } \\
\text { license), applicable to the online version of the article only. Distribution permitted for non- } \\
\text { commercial purposes only. }\end{array}$
\end{tabular}

\title{
The First Reported Case of Colonic Infection Caused by Candida tropicalis and a Review of the Literature
}

\author{
Surat Praneenararat \\ Division of Gastroenterology, Department of Medicine, Prince of Songkla University, \\ Songkhla, Thailand
}

\section{Key Words}

Candida tropicalis · Candida colitis · Colonic candidiasis · Candida infection of colon · Candida infection of large bowel

\begin{abstract}
Lower gastrointestinal tract infections caused by Candida species are rarely reported, and Candida albicans is the only pathogen that has been identified. The author reports a first case of colonic candidiasis caused by Candida tropicalis in a 55-year-old female with diabetes mellitus type 2, diffuse large B-cell lymphoma and neutropenia induced by chemotherapy. Diarrhea and fever were the presenting symptoms. Diagnosis was made based on deep tissue involvement on colonoscopy with biopsy and positive hemoculture. This alerted the physician to be aware of Candida non-albicans as a cause of colonic infection. Fungal culture should always be done to identify specific Candida species, leading to appropriate antifungal therapy. A review of the literature on colonic candidiasis is also presented here.
\end{abstract}

(c) 2014 S. Karger AG, Basel

\section{Introduction}

Fungal infections are increasingly being reported in immunocompromised patients. However, lower gastrointestinal tract infections caused by Candida species are rarely described. The reported cases of colonic candidiasis were due to Candida albicans in 3 and unspecified Candida also in 3 patients (table 1) [1-5]. Here we present a case of colonic infection caused by Candida tropicalis, which to the best of our knowledge is the first case. 
Praneenararat: The First Reported Case of Colonic Infection Caused by Candida tropicalis and a Review of the Literature

\section{Case Report}

A 55-year-old Thai female with diabetes mellitus type 2 was admitted to the hospital with a 1-month history of progressive, dull, aching, epigastric pain radiating to the back, persistent low-grade fever and a significant weight loss from 61 to $50 \mathrm{~kg}$. On physical examination, her body temperature was $37.8^{\circ} \mathrm{C}$, her blood pressure was $100 / 60 \mathrm{~mm} \mathrm{Hg}$ and her heart rate was $114 \mathrm{bpm}$. Epigastric tenderness without guarding was observed. Generalized peripheral non-tender lymphadenopathy, predominately in the right inguinal area, $3 \mathrm{~cm}$ in diameter, was detected. Abdominal computed tomography revealed multiple matted celiac, portahepatic, para-aortic and aortocaval nodes $0.6-4.6 \mathrm{~cm}$ in diameter. Pathological study of a right inguinal lymph node biopsy showed large round cells (fig. 1a) with CD20positive (fig. 1b) and CD3-negative immunohistochemical staining (fig. 1c), which was compatible with diffuse large B-cell lymphoma. A first cycle of CHOP chemotherapy was started, consisting of a single dose of $100 \mathrm{mg}$ cyclophosphamide i.v., a single dose of $70 \mathrm{mg}$ doxorubicin i.v., a single dose of 2,000 $\mathrm{g}$ g vincristine i.v. and $90 \mathrm{mg}$ oral prednisolone per day for 5 days. Imipenem $500 \mathrm{mg}$ i.v. every $6 \mathrm{~h}$ was also given for 3 days due to asymptomatic bacteriuria, which was diagnosed by the finding of $>100,000 \mathrm{CFU} / \mathrm{ml}$ Escherichia coli and Enterococci in urine culture.

One week after the chemotherapy was administered, the patient developed large voluminous mucous diarrhea (1,450-2,150 ml/day) and high-grade fever with a body temperature of $39^{\circ} \mathrm{C}$. A complete blood count showed a hemoglobin level of $7.3 \mathrm{~g} / \mathrm{dl}$, a white blood cell count of $490 / \mu \mathrm{m}$ and a platelet count of $46,000 / \mu \mathrm{m}$. Stool examination revealed a few white and a few red blood cells. Stool culture for enteropathic bacteria was negative. Empirical therapy with piperacillin and tazobactam, $4.5 \mathrm{~g}$ i.v. every $6 \mathrm{~h}$, was started; additionally, $400 \mathrm{mg}$ oral metronidazole three times a day and $125 \mathrm{mg}$ oral vancomycin every $6 \mathrm{~h}$ were administered to treat a presumed Clostridium difficile infection, despite a negative Clostridium difficile toxin test. After 10 complete days of antimicrobial treatment, the frequency of bowel movements, her stool character and her body temperature had not improved, so colonoscopy was done.

Multiple local clean-base ulcers, with sizes varying from 1 to $5 \mathrm{~cm}$, were detected at the cecum (fig. 2). HE and Gomori methenamine-silver staining of the biopsied tissue revealed budding yeasts and hyphae in the vessels as well as necrotic tissue consistent with Candida colitis (fig. 3). Blood culture and urine culture on the date of colonoscopy yielded $C$. tropicalis and $>100,000 \mathrm{CFU} / \mathrm{ml}$ C. tropicalis, respectively, confirming invasive candidiasis as per the revised EORTC/MSG criteria [6].

Intravenous fluconazole $200 \mathrm{mg}$ once daily for 5 days followed by oral fluconazole $200 \mathrm{mg}$ once daily to complete a 14-day treatment was given. The patient's fever and diarrhea resolved on the 2nd and 6th day, respectively. However, she subsequently developed further multiple infections during her stay and died.

\section{Consensus Statement}

Written informed consent has been obtained from the patient for the publication of this case report and any accompanying images. A copy of the written consent is available for review by the Editor of this journal. This case report complies with current ethical requirements. 
Praneenararat: The First Reported Case of Colonic Infection Caused by Candida tropicalis and a Review of the Literature

\section{Review of Candida Infections of the Colon}

Candida infections of the colon have so far been reported in an autopsy case series by Eras et al. [7] and in 6 other case reports [1-5]. However, in all cases, where fungal culture was discussed [1, 3, 4], C. albicans was the pathogen. Our patient is the first reported case of C. tropicalis infection of the colon.

C. tropicalis is an organism that can be found in the environment and also as an opportunistic human pathogen. It has been reported to colonize at several sites in the body including the skin, gastrointestinal, genitourinary and respiratory tracts [8-10]. It can be acquired endogenously in patients who are immunocompromised, including those admitted to an intensive care unit, suffering from malignancy, requiring prolonged catheterization, receiving broad-spectrum antibiotics and those with neutropenia [11, 12]. Alternatively, it can be acquired exogenously by direct contact [12]. The most common clinical manifestations of the invasive form are candidemia and candiduria [12].

The presented patient was unhealthy, neutropenic, received broad-spectrum antibiotics and also had candidemia and candiduria. These were typical features of $C$. tropicalis. Her diagnosis was primary gastrointestinal candidiasis because diarrhea preceded the eventually detected candidemia and candiduria by 10 days.

Only limited data is available on colonic candidiasis. In an autopsy case series [7], which contained no information regarding clinical presentations, colonic involvement occurred in $22 / 109(20 \%)$ cases of gastrointestinal candidiasis covering multiple sites of the gastrointestinal tract in 18/22 cases (82\%). Pathological findings were ulcer in 15/25 (60\%) cases, plaque in $6 / 25(24 \%)$ cases, erosion in $3 / 25(12 \%)$ cases and polyp in $1 / 25(4 \%)$ case. In a review of all available case reports (table 1) [1-5], all patients were immunocompromised, i.e. suffered from a malignancy, were on immunosuppressive agents, had AIDS, end-stage renal disease, neutropenia or diabetes mellitus. The disease could occur anywhere in the colon. The presenting symptoms were fever in 5/7 (71\%) cases, diarrhea in 4/7 (57\%) cases, abdominal pain in 2/7 (29\%) cases and lower gastrointestinal bleeding in 2/7 (29\%) cases. Dissemination was common, occurring in 5/7 (71\%) cases. As in our patient, treatment response in the two cases that received antifungal drugs was excellent $[4,5]$.

\section{Conclusion}

Candida infections of the colon are an entity rarely reported in the literature, and our patient is the first described case of $C$. tropicalis infection. Physicians should be aware of Candida species as a cause of colonic infection in patients with a high risk for opportunistic infections. Fungal culture to identify the specific species of candidiasis is crucial for the appropriate antifungal therapy, since drug sensitivity of some $C$. non-albicans species is different from those of $C$. albicans.

\section{Disclosure Statement}

Surat Praneenararat declares that he has no conflicts of interest. 


\begin{tabular}{l|l}
\hline \multicolumn{2}{l}{ Case Rep Gastroenterol 2014;8:199-205 } \\
\hline DOI: 10.1159/000363566 & $\begin{array}{l}\text { C 2014 S. Karger AG, Basel } \\
\text { www.karger.com/crg }\end{array}$ \\
\hline
\end{tabular}

Praneenararat: The First Reported Case of Colonic Infection Caused by Candida tropicalis and a Review of the Literature

\section{References}

1 Stylianos S, Forde KA, Benvenisty Al, Hardy MA: Lower gastrointestinal hemorrhage in renal transplant recipients. Arch Surg 1988;123:739-744.

-2 Prescott RJ, Harris M, Banerjee SS: Fungal infections of the small and large intestine. J Clin Pathol 1992;45: 806-811.

-3 Jayagopal S, Cervia JS: Colitis due to Candida albicans in a patient with AIDS. Clin Infect Dis 1992;15:555.

$\checkmark 4$ Kouklakis G, Dokas S, Molyvas E, Vakianis P, Efthymiou A: Candida colitis in a middle-aged male receiving permanent haemodialysis. Eur J Gastroenterol Hepatol 2001;13:735-736.

-5 Kitagawa KH, Kalb RE: Efalizumab treatment associated with Candida colitis. J Am Acad Dermatol 2008;59 (suppl 5):S120-S121.

-6 De Pauw B, Walsh TJ, Donnelly JP, Stevens DA, Edwards JE, Calandra T, et al: Revised definitions of invasive fungal disease from the European Organization for Research and Treatment of Cancer/Invasive Fungal Infections Cooperative Group and the National Institute of Allergy and Infectious Diseases Mycoses Study Group (EORTC/MSG) Consensus Group. Clin Infect Dis 2008;46:1813-1821.

7 Eras P, Goldstein MJ, Sherlock P: Candida infection of the gastrointestinal tract. Medicine (Baltimore) 1972;51:367-379.

-8 Basu S, Gugnani H, Joshi S, Gupta N: Distribution of Candida species in different clinical sources in Delhi, India, and proteinase and phospholipase activity of Candida albicans isolates. Rev Iberoam Micol 2003;20: 137-140.

9 Oksuz S, Sahin I, Yildirim M, Gulcan A, Yavuz T, Kaya D, Koc A: Phospholipase and proteinase activities in different Candida species isolated from anatomically distinct sites of healthy adults. Jpn J Infect Dis 2007;60: 280-283.

10 Negri M, Martins M, Henriques M, Svidzinski T, Azeredo J, Oliveira R: Examination of potential virulence factors of Candida tropicalis clinical isolates from hospitalized patients. Mycopathologia 2010;169:175-182.

11 Kontoyiannis DP, Vaziri I, Hanna HA, Boktour M, Thornby J, Hachem R, et al: Risk factors for Candida tropicalis fungemia in patients with cancer. Clin Infect Dis 2001;33:1676-1681.

-12 Nucci M, Colombo AL: Candidemia due to Candida tropicalis: clinical, epidemiologic, and microbiologic characteristics of 188 episodes occurring in tertiary care hospitals. Diagn Microbiol Infect Dis 2007;58: 77-82. 
Praneenararat: The First Reported Case of Colonic Infection Caused by Candida tropicalis and a Review of the Literature

Table 1. Summary of all data on reported colonic candidiasis cases

\begin{tabular}{|c|c|c|c|c|c|c|c|}
\hline & $\begin{array}{l}\text { Stylianos, } 1988 \text { [1] } \\
\text { (C. albicans) }\end{array}$ & $\begin{array}{l}\text { Prescott, } 1992 \text { [2] } \\
\text { (unspecified } \\
\text { Candida) }\end{array}$ & $\begin{array}{l}\text { Prescott, } 1992[2] \\
\text { (unspecified } \\
\text { Candida) }\end{array}$ & $\begin{array}{l}\text { Jayagopal, } 1992 \text { [3] } \\
\text { (C. albicans) }\end{array}$ & $\begin{array}{l}\text { Kouklakis, } 2001[4] \\
\text { (C. albicans) }\end{array}$ & $\begin{array}{l}\text { Kitagawa, } 2008 \text { [5] } \\
\text { (unspecified } \\
\text { Candida) }\end{array}$ & $\begin{array}{l}\text { Present case } \\
\text { (C. tropicalis) }\end{array}$ \\
\hline Age, years & 55 & 73 & 15 & 38 & 57 & 56 & 55 \\
\hline Gender & male & female & female & male & male & female & female \\
\hline Country & USA & England & England & USA & Greece & USA & Thailand \\
\hline $\begin{array}{l}\text { Underlying } \\
\text { disease }\end{array}$ & $\begin{array}{l}\text { renal } \\
\text { transplantation }\end{array}$ & $\begin{array}{l}\text { breast cancer, } \\
\text { Hodgkin's disease, } \\
\text { neutropenia }\end{array}$ & $\begin{array}{l}\text { Hodgkin's disease, } \\
\text { neutropenia }\end{array}$ & AIDS & $\begin{array}{l}\text { end-stage renal } \\
\text { disease }\end{array}$ & psoriasis & $\begin{array}{l}\text { diffuse large } \\
\text { B-cell lymphoma, } \\
\text { neutropenia, } \\
\text { diabetes mellitus }\end{array}$ \\
\hline Medication & $\begin{array}{l}\text { immunosuppressive } \\
\text { agents }\end{array}$ & chemotherapy & chemotherapy & & & efalizumab & chemotherapy \\
\hline $\begin{array}{l}\text { Clinical } \\
\text { presentations }\end{array}$ & LGIB & LGIB, fever & $\begin{array}{l}\text { abdominal } \\
\text { distension, fever }\end{array}$ & $\begin{array}{l}\text { watery diarrhea, } \\
\text { abdominal pain, } \\
\text { weight loss, fever }\end{array}$ & $\begin{array}{l}\text { loose stool diarrhea, } \\
\text { abdominal pain }\end{array}$ & $\begin{array}{l}\text { nausea, vomiting, } \\
\text { watery diarrhea, } \\
\text { fever }\end{array}$ & $\begin{array}{l}\text { mucous diarrhea, } \\
\text { fever }\end{array}$ \\
\hline $\begin{array}{l}\text { Duration until } \\
\text { presenting } \\
\text { symptoms }\end{array}$ & acute & not mentioned & not mentioned & 3 months & 10 days & 1 week & 1 week \\
\hline Dissemination & yes & yes & yes & yes & no & no & yes \\
\hline $\begin{array}{l}\text { Colonic } \\
\text { distribution }\end{array}$ & descending colon & not mentioned & $\begin{array}{l}\text { right side of the } \\
\text { colon }\end{array}$ & whole colon & $\begin{array}{l}\text { rectum up to the } \\
\text { descending colon }\end{array}$ & not mentioned & cecum \\
\hline $\begin{array}{l}\text { Endoscopic } \\
\text { findings }\end{array}$ & $\begin{array}{l}\text { friable mucosa } \\
\text { with submucosal } \\
\text { hemorrhage }\end{array}$ & ulcers & polyp & ulcers & polyp & white plaques & ulcers \\
\hline Treatment & $\begin{array}{l}\text { left hemicolectomy, } \\
\text { no antifungal drugs } \rightarrow \\
\text { died }\end{array}$ & not mentioned & not mentioned & none $\rightarrow$ died & $\begin{array}{l}\text { fluconazole } \rightarrow \\
\text { improved }\end{array}$ & $\begin{array}{l}\text { caspofungin } \rightarrow \\
\text { improved }\end{array}$ & $\begin{array}{l}\text { fluconazole } \rightarrow \\
\text { improved }\end{array}$ \\
\hline $\begin{array}{l}\text { Method of } \\
\text { diagnosis }\end{array}$ & $\begin{array}{l}\text { deep tissue invasion } \\
\text { from biopsy and } \\
\text { autopsy, positive } \\
\text { blood culture }\end{array}$ & $\begin{array}{l}\text { deep tissue } \\
\text { invasion from } \\
\text { autopsy }\end{array}$ & $\begin{array}{l}\text { deep tissue } \\
\text { invasion from } \\
\text { autopsy }\end{array}$ & $\begin{array}{l}\text { deep tissue } \\
\text { invasion from } \\
\text { autopsy }\end{array}$ & $\begin{array}{l}\text { respond to Rx and } \\
\text { normal follow-up } \\
\text { colonoscopy }\end{array}$ & respond to $\mathrm{Rx}$ & $\begin{array}{l}\text { deep tissue } \\
\text { invasion from } \\
\text { biopsy, positive } \\
\text { blood culture and } \\
\text { respond to Rx }\end{array}$ \\
\hline
\end{tabular}




\begin{tabular}{ll|l} 
Case Reports in & \multicolumn{2}{l}{} \\
\cline { 2 - 3 } Gastroenterology & Case Rep Gastroenterol 2014;8:199-205 & $\begin{array}{l}\text { c 2014 S. Karger AG, Basel } \\
\text { www.karger.com/crg }\end{array}$ \\
\cline { 2 - 3 } & DOI: 10.1159/000363566 &
\end{tabular}

Praneenararat: The First Reported Case of Colonic Infection Caused by Candida tropicalis and a Review of the Literature

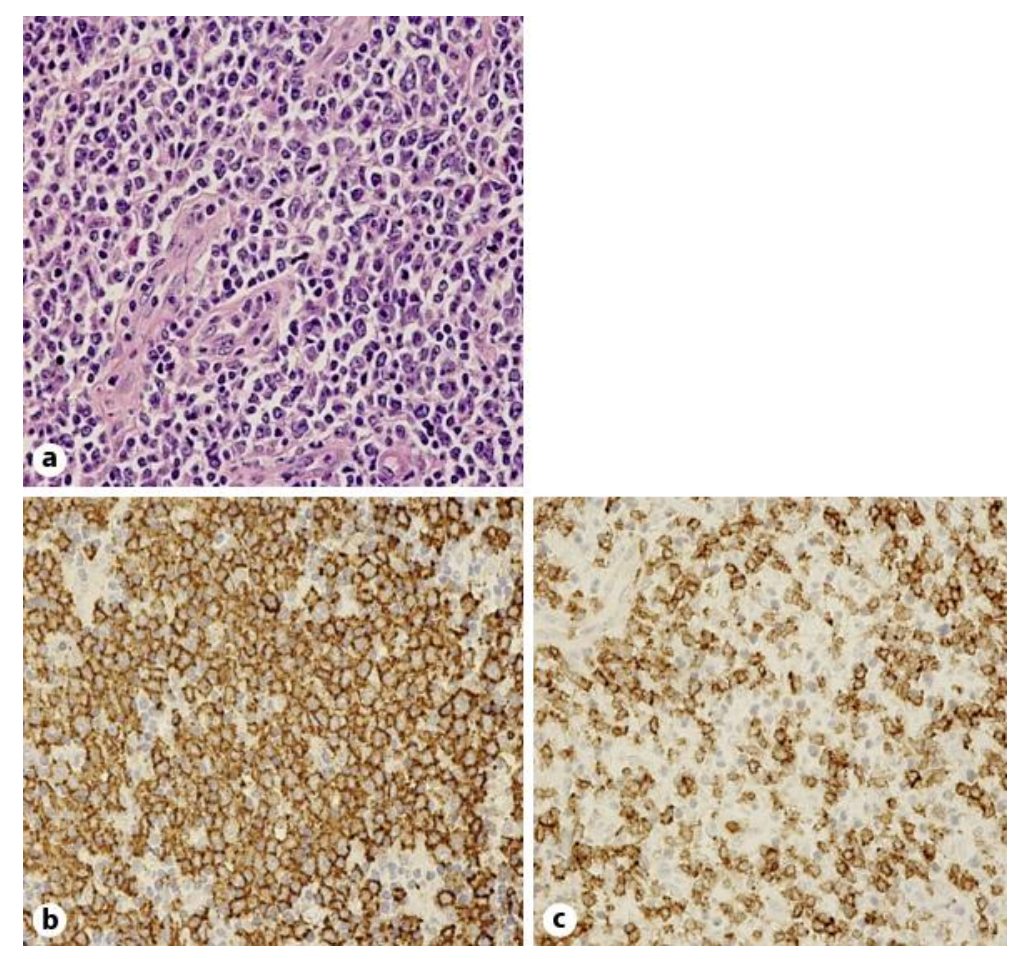

Fig. 1. Histopathology of the right inguinal lymph node biopsy. a Large round cells (HE staining, $\times 400$ ). b CD20-positive immunohistochemical staining $(\times 400)$. c CD3-negative immunohistochemical staining $(\times 400)$. These histopathological findings are compatible with diffuse large B-cell lymphoma. 


\begin{tabular}{ll|l} 
Case Reports in & \multicolumn{2}{l}{} \\
\cline { 2 - 3 } Gastroenterology & Case Rep Gastroenterol 2014;8:199-205 & $\begin{array}{l}\text { @ 2014 S. Karger AG, Basel } \\
\text { www.karger.com/crg }\end{array}$ \\
\cline { 2 - 3 } & DOI: 10.1159/000363566 &
\end{tabular}

Praneenararat: The First Reported Case of Colonic Infection Caused by Candida tropicalis and a Review of the Literature

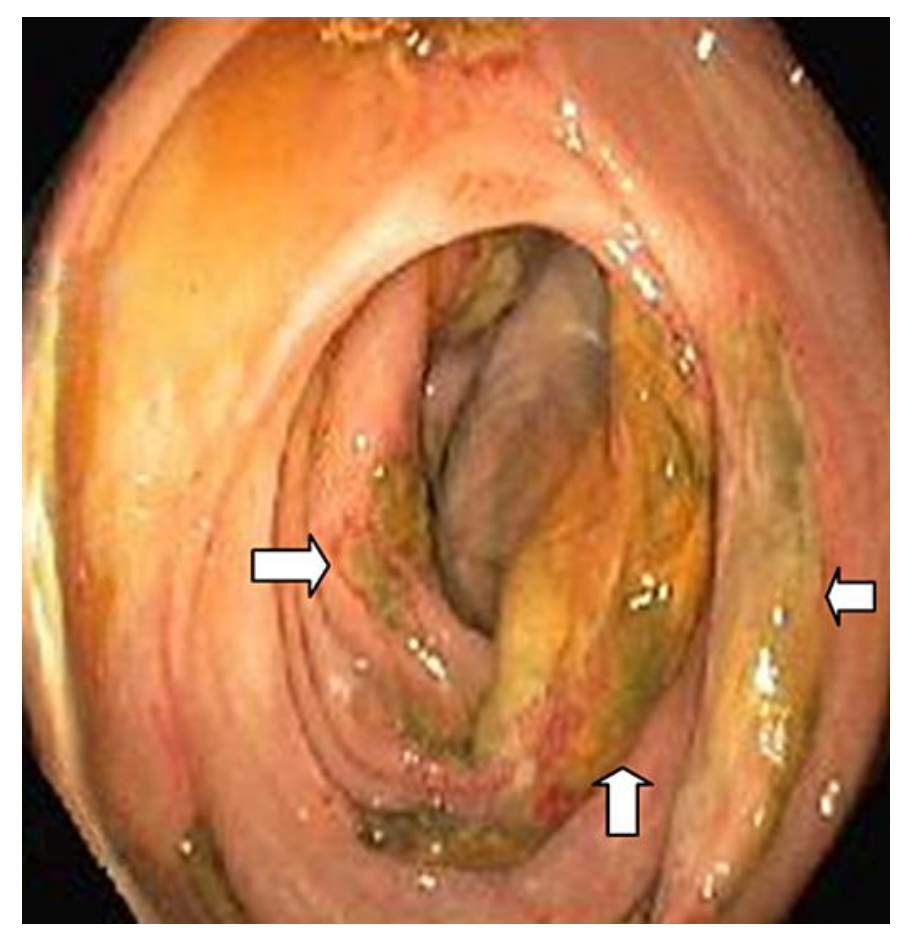

Fig. 2. Multiple cecal ulcers. Colonoscopy showed multiple local clean-base ulcers (arrows) with yellowish exudates and surrounding erythematous edematous mucosa at the cecum. The sizes of the ulcers varied from 1 to $5 \mathrm{~cm}$ in diameter.

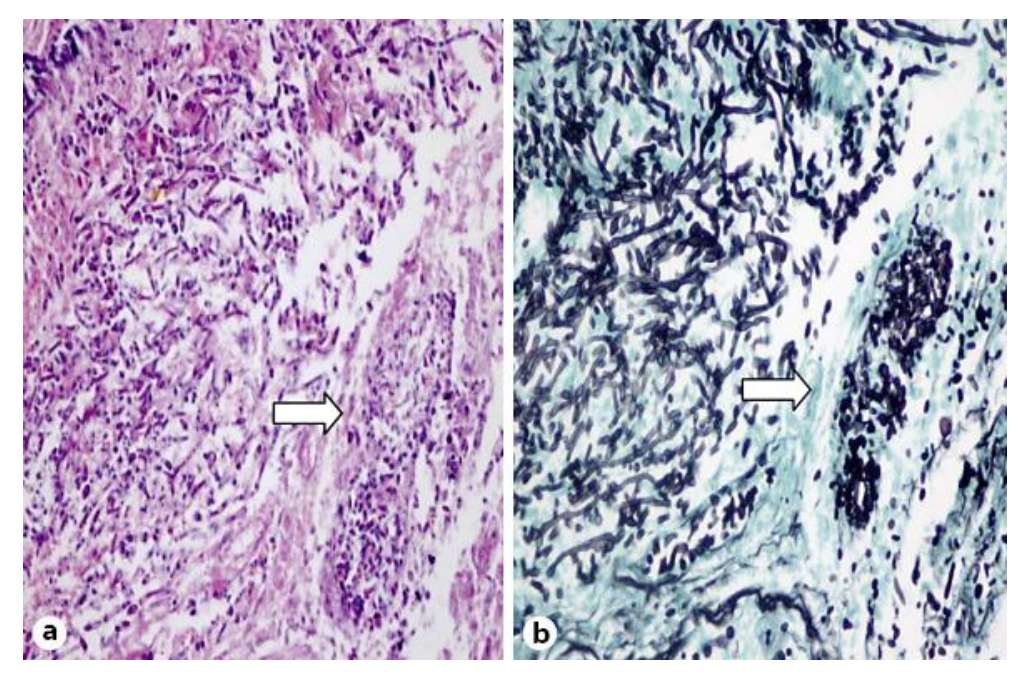

Fig. 3. Microscopic appearance of the cecal ulcers caused by Candida infection. a HE staining. $\times 400$. b Gomori methenamine-silver staining. $\times 400$. Biopsies of the cecal ulcers revealed budding yeasts with hyphae in the vessels (arrows), which invaded the deep tissue, and thus represented a true infection and no contamination. 